\title{
Effect of Work Climate and Work Motivation on the Performance of Public Elementary School Teachers in 2x11 Kayu Tanam District, Padang Pariaman Regency
}

\author{
Sri Nofita ${ }^{1}$, Bustari Muchtar ${ }^{2}$, Susi Evanita ${ }^{3}$ \\ ${ }^{1}$ Universitas Negeri Padang, Padang and Indonesia, $\square$ srinofita08@gmail.com \\ ${ }^{2}$ Universitas Negeri Padang, Padang and Indonesia, $\square$ bustarimuchtar@gmail.com \\ ${ }^{3}$ Universitas Negeri Padang, Padang and Indonesia, $\square$ susievanita @fe.unp.ac.id
}

\begin{abstract}
The purpose of this study is to analyze the Influence of Work Climate, and Work Motivation on the Performance of Public Elementary School Teachers in 2x11 Kayu Tanam District, Padang Pariaman Regency. This study used 300 respondents as the sample. The data analysis technique of this research is path analysis. The results showed that work motivation and performance had a significant effect on the teacher's work climate of Public Elementary School Teachers in 2x11 Kayu Tanam District, Padang Pariaman Regency.
\end{abstract}

Keywords: Work Climate, Work Motivation, Teacher Performance

\section{Introduction}

One aspect of development that fully addresses it in educating the nation's life is the field of education. Education is a potential empowerment process for humans as individuals and communities that function in addition to empowering potential, as well as to develop and control this potential so that it is useful to improve the quality of humans themselves.

The quality of teacher performance greatly determines the quality of educational outcomes, because the teacher is the figure who most often interacts with students during the learning process. Meanwhile the measure of teacher performance can be seen from the sense of responsibility in carrying out the mandate. His profession is a sense of moral responsibility that lies on his shoulder, all will appear in his obedience and loyalty in carrying out his duties as a teacher in the classroom and outside the classroom.

According to Hasibuan (2010: 69) performance is a result of work achieved by someone in carrying out the tasks assigned to him, which is based on skills, experience and sincerity as well as time. The success of a school can be determined by teacher performance, proper performance improvement can only be done based on the results of the evaluation of the performance itself, because the results of the performance evaluation indicate the level of management of a person in carrying out the tasks that are his responsibility. Low performance will indicate a lack of organizational management skills which results in the achievement of organizational goals. Conversely, high performance reflects the ability to manage the organization well, which ultimately has an impact on the performance of the organization itself. A teacher is said to have good performance if he can carry out his duties professionally.

Performance is a necessity that is understood and understood by several parties to find out the level of success produced by institutions that support the vision and mission embraced by a school and also learn the positive and negative ways of an operational policy. Improving performance has a very important meaning in efforts to improve to achieve school goals, of course there will be factors that will make teacher's performance better. One of them is work challenges and work motivation at school.

A conducive work climate creates a good working atmosphere and harmonious interpersonal relationships that will encourage teachers to be diligent and diligent in their work so that the teacher's performance improves and the completion of the assignment will be a place of time. This is in line 
with the research conducted by Kingis et al. (2000), finding that between work climate has a positive relationship with company performance.

The results of research conducted in Malaysia relating to the work climate indicate that, "schools that excel in Malaysia show an open climate." From the results of this study it is known that in an open climate atmosphere there is a good relationship between schools with teachers, teachers and students respecting one another, teachers do not look down on students who are not smart or in other words students are respected regardless of the stage of their academica chievement (Supardi:2016).

Motivation is one of the factors supporting success in learning and automatically also supports the success of the teacher in managing the learning process. According to Danim (2012: 2) "motivation is defined as strength, encouragement, need, enthusiasm, pressure, or mechanism in psychology that encourages a person or group of people to achieve certain achievements in accordance with what is desired". Motivation is related to whether a person is satisfied or not in his interactions with those who influence him.

For teachers, the purpose of motivation is to arouse passion, as Piet (2008: 3) argues that passion from high morale enables teachers to create fun teaching and learning situations for students. A pleasant learning situation is expected to be able to move or encourage students to learn and want to improve learning achievement, so that educational goals are achieved in accordance with what is expected and determined by the school. able to retain employees so that they are motivated and able to show high performance.

Customer satisfaction in order to create then what is perceived by the customer about the quality of the product must be greater than expected so as to create satisfaction which in turn they will be loyal to the product. Murtiyanto (2014), found that product quality gives positive and significant influence to consumer loyalty through consumer satisfaction. This shows that high product quality tends to create high consumer loyalty also through the satisfaction of every consumer and vice versa. Utami (2015), found the relationship between product quality and loyalty through customer satisfaction. By improving the ability of a product will create a competitive advantage so that customers become more loyal. Customer satisfaction is highly dependent on how the quality of products offered. Consumers will be loyal if the products obtained or purchased by consumers in accordance with the expected so that the consumer's satisfaction created a consumer that makes it difficult to switch to other products and still use the product.

Based on interviews with several teachers in Public Elementary Schools in 2x11 Subdistrict Kayu Tanam can be denied, there are still teachers who are less motivated to improve their performance. This is proven to increase compilation and not increase students in noisy teaching compilation classes. Padang pariaman Regency, So, the title of this research is "the effect of Work Climates, and Work Motivation on the Performance of Public Elementary School Teachers in 2x11 Kayu Tanam District, Padang Pariaman Regency".

\section{Methods}

Based on the formulation of the problem and the purpose of the study, the type of research used is causative which is intended to see the work climate and work motivation against the performance of public elementary school teachers in 2x11 Kayu Tanam District, Padang Pariaman Regency. The population of this research is all the teachers in the Padang Pariaman Regency. Data collection using questionnaires by giving or collecting questionnaires to respondents. This study uses survey techniques with 300 respondents. The analytical method used in this study is the analysis of exogenous variable pathways and endogenous variables.

\section{Results and Discussion}

Path analysts are used to see the effect of exogenous variables on endogenous variables through other endogens (intervening variables) and measure the direct and indirect effects of one variable on other variables. The following is the result of the first substructure of analysis in this study: 
Table 1 Results of First Sub Structure Analysis

\begin{tabular}{lcccc}
\hline \multicolumn{1}{c}{ Variable } & Coefficient & t-value & Sig. & Result \\
\hline Work Climate $(\mathrm{X} 1)$ & 0,719 & 9,883 & 0,000 & Significant \\
\hline R Square $=0,518$ & & & & \\
\hline
\end{tabular}

Source: Primary Data Processed (2017)

From the above calculation results, the coefficient of each independent variable along with $t$ test results as follows:

a. The coefficient of work climate is $0.0,719$ and the $t$-value is 9,883 in sig. 0,000 which is smaller than alpha 0.05 . These results indicate that there is an influence of the work climate on work motivation.

The Calculations show that there is an influence of work climate on work motivation. Based on the above calculations, the analysis diagram can be shown as follows

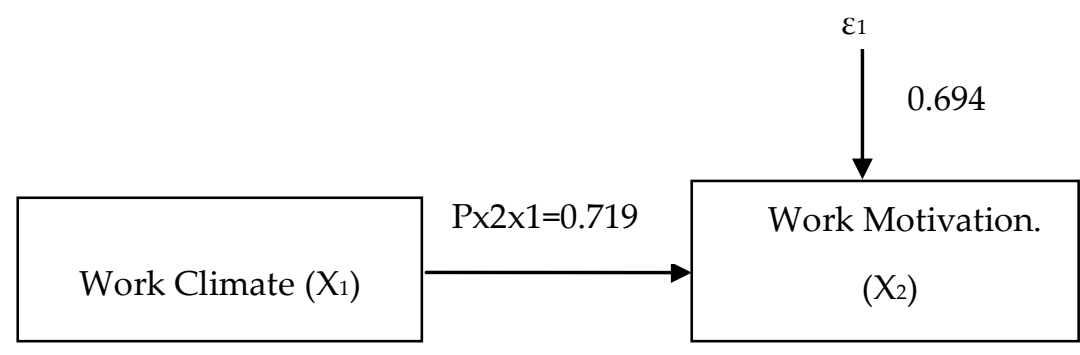

Figure 1 First Sub-Structure of Path Analysis

Based on the results of data analysis, that work climate has an effect on work motivation. Therefore, data analysis can proceed to the second sub-structure.

Analysis of the second structure to determine the effect of work climate (X1) and work motivation $(\mathrm{X} 2)$ on teacher performance $(\mathrm{Y})$ Public Elementary Schools in 2x11 Kayu Tanam district Padang Pariaman Regency in the following table:

Table 2 Results of Second Sub Structure Analysis

\begin{tabular}{lcccc}
\hline \multicolumn{1}{c}{ Variable } & Coefficient & t-value & Sig. & Result \\
\hline Work Climate $(\mathrm{X} 1)$ & 0,789 & 12,067 & 0,000 & Significant \\
\hline Work Motivation $(\mathrm{X} 2)$ & 0,149 & 2,281 & 0,025 & Significant \\
\hline R Square $=0,814$ & & & & \\
\hline
\end{tabular}

Source: Primary Data Processed (2017)

From the above calculation results, the coefficients of each independent variable along with $t$ test results as follows:

a. The coefficient of Working Climate is 0.789 and the $t$-value is 12.067 in sig. 0,000 which is smaller than alpha 0,05 . This result shows there is effect of the work climate to teacher performance.

b. The coefficient of Work Motivation is 0.149 and the t-value is 2,281 in sig. 0.025 which is smaller than alpha 0.05 . This result shows there is effect of the work motivation to teacher performance.

The calculations show that there is an influence of Work Climate on teacher performance, and the influence of Work Motivation on Teacher Performance. Based on the above calculation, it can be shown the analysis diagram as follows: 


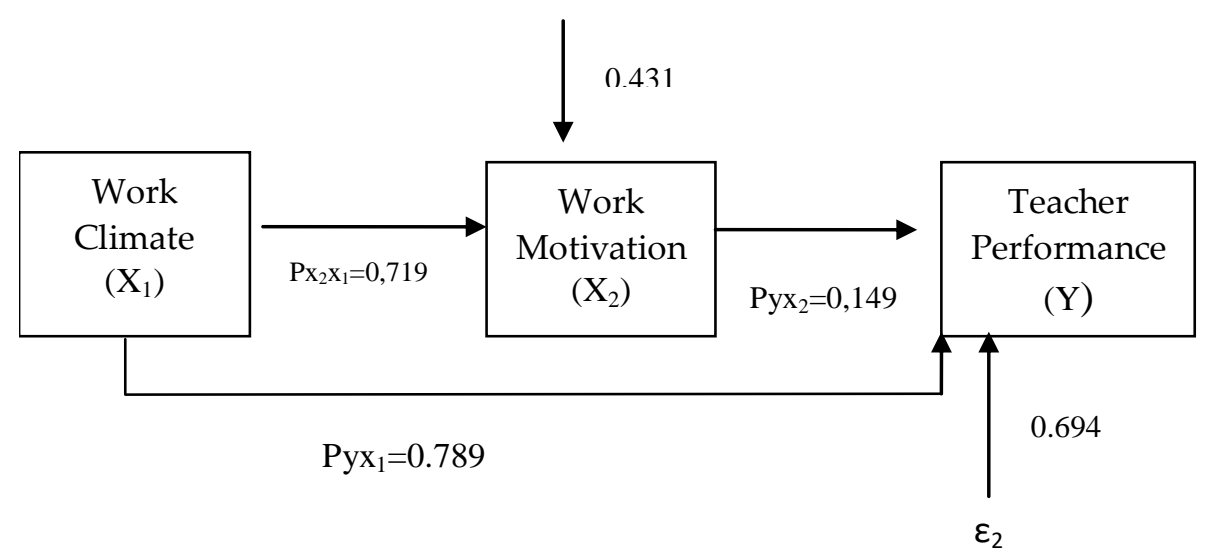

Figure 2 Second Sub-Structure of Path Analysis

\section{Hypothesis testing}

Hypothesis 1

From result of $\mathrm{t}$ test show value of path coefficient for Work Climate variable to Work Motivation (Px2x1) is 0,719 with t-value for Work Climate variable 9,883at significant value 0,000<0,05 then Ho rejected Ha accepted, there is significant influence between Work Climate to Work Motivation of Elementary Schools in 2x11 Kayu Tanam district Padang Pariaman Regency.

Hypothesis 2

From result of $\mathrm{t}$ test show value of path coefficient for product Work Climate to teacher performance (Pyx1) is 0,789with t-value for Work Climate variable 2,281 at significant value $0,000<0,05$ so Ho is rejected, Ha accepted, there is significant influence between Work Climate to teacher performance of Elementary Schools in 2x11 Kayu Tanam district Padang Pariaman Regency.' Hypothesis 3

From result of $\mathrm{t}$ test show value of path coefficient for Work Motivation variable to teacher performance (Рyx2) is 0,149 with $\mathrm{t}$-value for Work Motivation variable 2,470 at significant value 0,025 $<0,05$ so Ho rejected Ha accepted, there is significant influence between Work Motivation to the teacher performance of Elementary Schools in 2x11 Kayu Tanam district Padang Pariaman Regency .

\section{Discussion}

Effect of Work Climate on Work Motivation of Public Elementary School Teachers in 2x11 Kayu Tanam District, Padang Pariaman Regency. Based on the hypothesis test it is known that the work climate has a significant influence on work motivation of SDN in 2x11 Kayu Tanam Subdistrict, Padang Pariaman Regency. The better the work climate will certainly increase the motivation of working teachers of the 2x11 Kayu Tanam Elementary Schoolin Padang Pariaman District.

The path coefficients of the influence of the work climate have a significant effect on the performance of teacher DX2X1 is 0.719 . Thus, the work climate is a factor that influences work motivation. The better the work climate is given will certainly increase workmotivation.

The results of this study are in line with the opinion According to As'ad (2002: 45) work motivation is something that can create enthusiasm or improve work. Thus, motivation is usually referred to as job booster. The findings of this study are in line with research conducted by Budiyanto (2017) and Dewa (2011) which states that the work climate has a positive and significant effect on work motivation.

Effect of Work Climate on Teacher Performance of Public Elementary School Teachers in 2x11 Kayu Tanam District, Padang Pariaman Regency 
Based on the hypothesis test it is known that the work climate has a significant influence on the performance of teachers in the Elementary School of 2x11 Kayu Tanam Subdistrict, Padang Pariaman Regency. The better working climate will certainly improve the teacher's performance.

The path coefficients of the influence of the work climate have a significant effect on teacher performance. Pyx $1=0.789$ Thus the work climate is a factor that influences teacher performance. The better the work climate is given will certainly improve teacher performance.

The results of this study are in line with the opinion of Seters (2009: 101) suggesting that the work climate is an internal environment that represents the natural factors of the organization that creates a culture and social environment where the achievement activities take place. ) and Carudin (2011) which states that the work climate has a positive and significant effect

Effect of Work Climate and Work Motivation on Teacher Performance of Public Elementary School Teachers in 2x11 Kayu Tanam District, Padang Pariaman Regency

Based on the hypothesis test it is known that the work climate through work motivation has a significant influence on the performance of the SDN in 2x11 Kayu Tanam Subdistrict, Padang Pariaman Regency. The better work climate through work motivation will certainly improve the performance of teachers in the Elementary School of 2x11 Kayu Tanam Subdistrict, Padang Pariaman Regency.

The path coefficient obtained by the influence of work climate through work motivation has a significant effect on Pyx2 teacher performance $=0.149^{\prime}$ Thus the work climate through work motivation is a factor that affects teacher performance. The better the work climate through the motivation of work provided will certainly improve teacher performance.

The results of this study are in line with the opinion according to Mathis and Jackson (2009: 142) performance appraisal (Performanc Appraisal) is the process of evaluating how well e mployees do their work when compared to a standard set and then communicating that information. The findings of this study are in line with the research conducted by Budiyanto (2017) and Dewa (2011) which states that the work climate and work motivation have a positive and significant effect on teacher performance.

\section{Conclusions}

In accordance with the analysis and discussion of the results of hypothesis testing that has been done, it can be proposed several important conclusions which are the answers to a number of problems that were proposed in this study, namely: 1) The work climate has a positive and significant effect on teacher performance carried out at the 2x11 Kayu Tanam District Elementary School in Padang Pariaman Regency, meaning that a conducive working climate strongly supports the improvement of teacher performance. 2) The work climate has a positive and significant effect on the motivation of work done at the 2x11 Kayu Tanam District Primary School in Padang Pariaman Regency, meaning that a conducive work climate will increase teacher motivation for its performance. 3). Work climate and work motivation have a positive and significant effect on teacher performance in the 2x11 Kayu Tanam District Primary School in Padang Pariaman Regency, meaning that the work climate has an effect on teacher performance through his work motivation.

\section{References}

As'ad, Mohamad. (2002). Psikologi Industri Seri Ilmu Sumber Daya Manusia. Liberty,Yogyakarta

Arikunto, Suharsimi. 2010. ProsedurPenelitianSuatuPendekatanPraktik.Jakarta:RinekaCipta

Baron, R.A \& Greenberg, J. 2010.Behaviour In Organizasional. Understanding And Managing The Human Side of Work. New York: Allyn and Bacom.

Budianto Apri, 2017. “Iklim Kerja Berpengruh Terhadap Motivasi Dan Kinerja Pegawai : Studi Pada Perbankan Di Wilayah Kabupaten Ciamis.Jurnal Aplikasi Bisnis Dan Manajemen, Vol. 1 No. 1, September 2017

Carudin.2011. Pengaruh Kepemimpinan Kepala Sekolah dan Iklim Kerja Terhadap Kinerja Guru SMPN Sibolga. 
Dewa Putu Parta (2011). "Konstribusi Kemampuan Manejerial Kepala Sekolah, Iklim Kerja Dan Motivasi Kerja Terhadap Kinerja Guru Sekolah Dasar Negeri Di Kecamatan Suragala"; Jurnal Education Vol 6. No 2 des 2011 hal 120-137

Gibson, James L. Ivencevich, Donnely, Jr. 2009, Organisasi: Prilaku, Struktur, Proses, Edisi I, Jakarta: Bina Rupa Aksara.

Hasibuan, Melayu S.P. 2010. ManajemenDasar. Jakarta: Bumi Aksara

Kangis, P., Gordon, D. and Williams, S. (2000), “Organisational climate and corporate performance: an empirical investigation",Management Decision, Vol. 38 No. 8, pp. 531-540.

Mangkunegara. 2010. EvaluasiKinerjaSumberDayaManusia. Bandung :RefikaAditama.

Mathis, Robert L dan Jackson J.H, 2009. Manajemen Sumber Daya Manusia, Salemba Empat, Jakarta.

Rahsel, Yoeyong (2017). KinerjaPegawaiUniversitasPadjadjaranBandung:Iklim Kerja Dan Motivasi Kerja.Jurnal Manajemen Magister, Vol. 03. No.01, Januari 2017

Staw, Barry M, 2008. Psychological Dimension of organizational Behaviour. Singapore: Mc Millan Publishing Co.

Steers, Richard M, 2009.Efektivitas Organisasi, Terjemahan Magdalena Jamin, Jakarta: Erlangga

Suwatno.2011.ManajemanSDM Dalam Organisasi Publik dan Bisnis.Bandung: CV. Alfabeta 